\title{
4-25-2017
}

\section{Fungal Infections From Human and Animal Contact}

Dennis J. Baumgardner

Follow this and additional works at: https://aah.org/jpcrr

Part of the Bacterial Infections and Mycoses Commons, Infectious Disease Commons, and the Skin and Connective Tissue Diseases Commons

\section{Recommended Citation}

Baumgardner DJ. Fungal infections from human and animal contact. J Patient Cent Res Rev. 2017;4:78-89. doi: 10.17294/2330-0698.1418

Published quarterly by Midwest-based health system Advocate Aurora Health and indexed in PubMed Central, the Journal of Patient-Centered Research and Reviews (JPCRR) is an open access, peer-reviewed medical journal focused on disseminating scholarly works devoted to improving patient-centered care practices, health outcomes, and the patient experience. 


\title{
Fungal Infections From Human and Animal Contact
}

\author{
Dennis J. Baumgardner, MD \\ Aurora University of Wisconsin Medical Group, Aurora Health Care, Milwaukee, WI; Department of Family Medicine \\ and Community Health, University of Wisconsin School of Medicine and Public Health, Madison, WI; Center for Urban \\ Population Health, Milwaukee, WI
}

\begin{abstract}
Fungal infections in humans resulting from human or animal contact are relatively uncommon, but they include a significant proportion of dermatophyte infections. Some of the most commonly encountered diseases of the integument are dermatomycoses. Human or animal contact may be the source of all types of tinea infections, occasional candidal infections, and some other types of superficial or deep fungal infections. This narrative review focuses on the epidemiology, clinical features, diagnosis and treatment of anthropophilic dermatophyte infections primarily found in North America. Other humanacquired and zoonotic fungal infections also are discussed in brief. (J Patient Cent Res Rev. 2017;4:78-89.)
\end{abstract}

Keywords Arthrodermataceae, dermatomycoses, tinea, zoonoses, Candida

I n previous publications we have discussed fungal infections resulting from exposure to soil, freshwater, and home and yard environments. ${ }^{1-3} \mathrm{In}$ this fourth article of the series, we will discuss fungal infections that may be acquired through contact with humans or certain animals. While it is true that "with rare exception, mycoses are not transmissible from patient to patient," fungi that are "contagious" often involve spread from normal hosts and include some of the most commonly known and acquired fungal infections..$^{5-8}$ Similarly, a few important infections are transmitted to humans from animals. ${ }^{5-13}$ Outbreaks have occurred involving both scenarios of spread. ${ }^{11-14}$

This narrative review will focus on the anthropophilic and zoophilic fungal infections likely to be found in North America, particularly the main group of infections labeled dermatophytes. Other contagious fungal infections acquired from human or animals are briefly addressed.

Correspondence: Dennis J. Baumgardner, MD, Aurora Sinai Medical Center, 1020 N. 12th Street, \#4180, Milwaukee, WI, 53233, T: 414-219-5191,

Email: dennis.baumgardner@aurora.org

\section{Dermatophyte Infections Acquired Through Direct and Indirect Human Contact}

Dermatophyte infections are those in which the offending agents rely on degradation of keratin, usually in dead cells of the outer epidermis (stratum corneum). ${ }^{6-8}$ These infections can involve areas throughout the superficial body from scalp and hair shafts to feet and nails (Table 1). ${ }^{8}$ In persons with normal immune systems, dermatophytes generally do not grow beyond the nonliving stratum corneum. ${ }^{6}$ One exception to this is Majocchi's granuloma, in which the infecting fungi invade the dermal and subcutaneous tissues, perhaps in response to minor trauma or irritation at the involved skin site. ${ }^{15,16}$

\section{Epidemiology}

The etiologic fungi of dermatophyte infections may be anthropophilic (ie, preferring human hosts and acquired from other humans), zoophilic (acquired from animal hosts) or geophilic (acquired from soil). ${ }^{5-8}$ Anthrophilic and zoophilic fungi are common etiologies of dermatomycoses, whereas geophilic fungi remain rare.

The frequency of dermatophyte infections varies by geographic area, age, gender and personal activities. ${ }^{6,7}$ Trichophyton tonsurans may be associated with 
Table 1. Common Superficial Dermatophyte Infections

\begin{tabular}{lll}
\hline Name & Lay term & Description \\
\hline Tinea capitis & Ringworm of scalp & Infection of the scalp and hair shafts \\
Tinea corporis & Ringworm of body & Infection of general areas of the body \\
Tinea barbae & Ringworm of beard & Infection of the skin in parts of the beard and mustache areas \\
Tinea faciei & Ringworm of face & Infection of the face exclusive of beard and mustache areas \\
Tinea manuum & Ringworm of hand & Infection of the hands \\
Tinea cruris & Jock itch & Infection of the groin \\
Tinea pedis & Athlete's foot & Infection of the foot \\
Tinea unguium & Nail fungus & Infection of the nail, a subset of onychomycosis \\
\hline
\end{tabular}

crowded living conditions and economic deprivation. ${ }^{12}$ Microsporum canis (predominantly acquired from cats and dogs) remains a cause of tinea capitis in the United States, including Puerto Rico. ${ }^{12}$ A general predominance of dermatophyte infections in males may be due to inhibition of the fungi in women by progesterone, ${ }^{7}$ but the particular infecting agent also may affect gender distribution. ${ }^{12,17}$ The etiologic fungi of tinea capitis (scalp ringworm) have shifted over the past several decades in the United States. ${ }^{12} T$. tonsurans has significantly supplanted Microsporum audouinii; both are anthropophilic fungi. ${ }^{12}$ Similar shifts in predominance of etiologic dermatophytes have occurred in Canada and Europe. ${ }^{12,18}$

Tinea capitis, the most contagious of dermatophyte infections, ${ }^{19}$ may be more often transmitted from one human to another by sluffed epithelial cells and hair than by direct contact. Both $T$. tonsurans and $M$. audouinii may be found on clothing and bedding or furniture, the former on combs and brushes. ${ }^{12}$ Thus, fomites are important players in these infections.

Asymptomatic scalp carriage rates may approach 50\% depending on the locale and species distribution. ${ }^{19}$ Scalp carriage predominately involves anthropophilic dermatophytes, is highest among early-school-age children and has variable gender ratios. ${ }^{19}$ The relative risk of spread from asymptomatic scalp carriers versus those with active ringworm is unclear but likely related to spore load. ${ }^{19}$ Tinea capitis infections may be passed from one generation to another within household families due to low-grade infections or asymptomatic carriers. $^{12}$ Recently, an outbreak of M. audouinii tinea capitis in elementary schools in Germany was reportedly related to a family returning from vacation in Africa. ${ }^{20}$ The authors stressed the importance of traveling and migration in the changing epidemiology of tinea capitis dermatophytes. ${ }^{20}$

The less contagious tinea corporis, manuum and cruris tend to be caused by the "cosmopolitan" anthropophilic dermatophytes Trichophyton rubrum, Trichophyton mentagrophytes complex (which is sometimes zoophilic) and Epidermophyton floccosum, as well as the zoophilic M. canis. ${ }^{7}$ Spread of these dermatophytes, predominantly the arthroconidia (ie, spores formed by breaking up of a hypha, the vegetative filament of the fungus), is more common within closer knit communities such as schools, sports teams, prisons or families. In addition to aforementioned items, spread may be aided by clothes, towels, bedding or contaminated furniture/changing rooms, or occur as the result of direct contact. ${ }^{9,13,21-23}$

Dermatophytes also have been identified in public baths and swimming pools, ${ }^{24}$ and epidemiologic evidence has suggested an association between sources such as swimming pools and infections such as tinea pedis. ${ }^{14}$ Dermatophyte foot and toenail infections have been spread in worship spaces and other public environments (eg, locker rooms, fitness centers) where persons remove their shoes. ${ }^{6}$

The importance of contagious sports-related tinea infections was mostly downplayed by one author as not a major problem to sports-medicine physicians. ${ }^{22}$ However, the prevalence of tinea infections (usually T. rubrum and T. tonsurans in the United States) in $20 \%$ of high school athletes and $7 \%$ of college athletes $^{23}$ (and up to $60 \%$ in college wrestlers ${ }^{6}$ ) is not trivial. Such infections include "tinea gladiatorum," 
which are dermatophyte infections spread by close athletic contact, like wrestling, and for which manifestations may be related to clothing, helmets and areas of superficial trauma. ${ }^{25}$ While the warm, moist (conditions conducive to fungus growth and reproduction) environments of sweaty clothing and helmets certainly increase the risk of superficial fungal infections, skin-to-skin contact and shared fomites and facilities promote person-to-person spread..$^{6,23}$

\section{Pathophysiology}

Dermatophyte fungi depend on keratin and other skin components for growth. ${ }^{6,826}$ This dependence and their general inability to grow above $37^{\circ} \mathrm{C}$ restricts infection by these organisms primarily to the superficial layers of the body, exclusive of the mucous membranes. ${ }^{6,8}$ The arthroconidium must first adhere to the keratinized skin surface. Carbohydrate microfibrils on the fungal cell surface anchor the microorganism to the keratinocytes and possibly to other arthroconidia. ${ }^{6,26}$ To invade hair shafts, dermatophytes create a specialized structure called a penetrating organ. ${ }^{6}$ Once anchored, the arthroconidia germinate and form a web or complex of hyphae, and invasion of sublayers occurs. ${ }^{6,26}$ Multiple enzymes, including keratinases, elastases and other proteases directed against skin components, are released to invade skin cells or penetrate hair. ${ }^{6,26,27}$ Essentially, these organisms digest their food (ie, components of human skin cells) external to their own fungal cells prior to import and metabolism (a rather unsavory thought).

Innate peptide and medium-chain fatty acid production help ward off invading fungi. ${ }^{27}$ However, several factors increase the likelihood of successful dermatophyte infection, including immune status, atopy, diabetes mellitus (onychomycosis), circulatory disorders, prior trauma or deformity, occlusive boots or clothing, occupational factors and age (eg, tinea capitis in school-age children is likely related to the particular fatty acid composition in the stratum corneum, elderly are more susceptible to onychomycosis). ${ }^{6,13}$ The degree of inflammation depends on the particular fungus and the host response. ${ }^{6,12}$

\section{Clinical Presentations}

Tinea Capitis: Tinea capitis presents as patches of hair loss with sometimes irregular, but generally well- demarcated, borders. The lesions may coalesce and include much of the scalp if left untreated. ${ }^{6,228}$ The disease is most common in children and uncommon in adults, and there are four types described in the United States. ${ }^{6}$ The seborrheic type, an inflammatory and hyperkeratotic form, is the most common and includes erythema, patchy or matted alopecia, pustules, nodules, crusting and weeping (Figure 1). It often presents with occipital lymphadenopathy in children. ${ }^{6}$

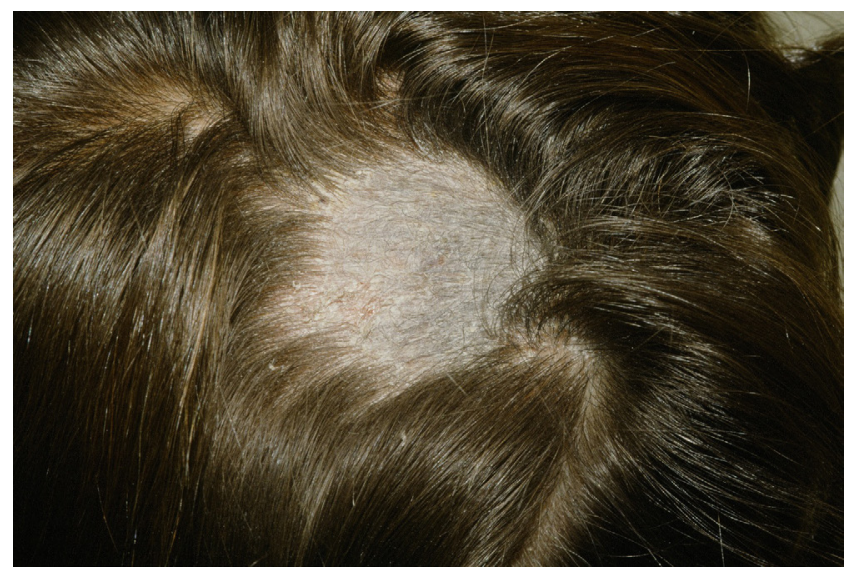

Figure 1. Seborrheic tinea capitis. (Photograph courtesy of RegionalDerm.com and Dr. Gary White.)

Also common is the black dot form (noninflammatory but scaly), which is usually caused by T. tonsurans and Trichophyton violaceum (Figure 2). The black dots (very short hair remnants) are caused by the organisms sporulating within the hair shaft such that it fractures a few millimeters from the scalp surface. ${ }^{6,8,27}$

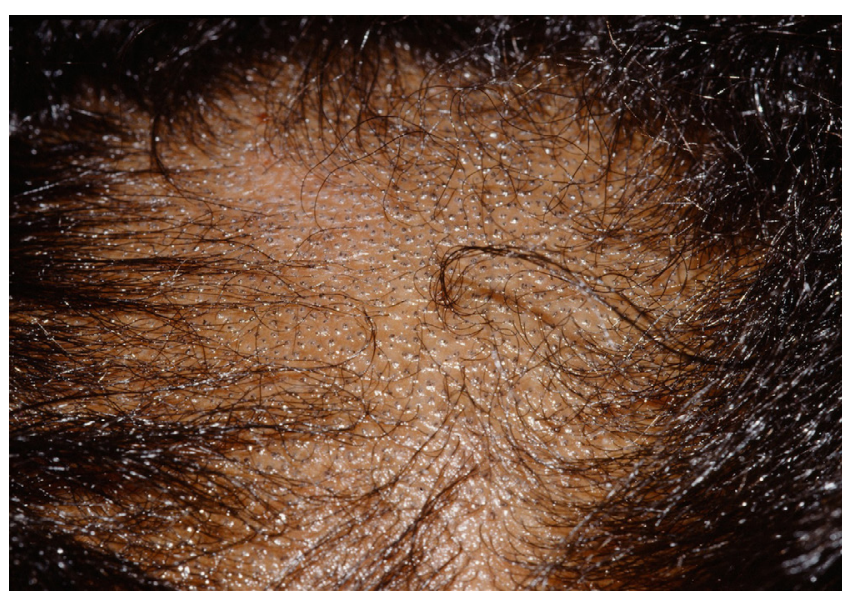

Figure 2. Black dot tinea capitis. (Photograph courtesy of RegionalDerm.com and Dr. Gary White.) 
The alopecia areata type (smooth alopecia in patches without inflammation or scaling) is rare. ${ }^{6}$ Also unusual is "kerion," an inflamed, heaped-up, boggy, tender mass with pustules and associated lymphadenopathy (Figure 3). Kerion is usually caused by T. tonsurans and $M$. canis, is produced by a cell-mediated response to a tinea capitis, and may cause scarring alopecia. ${ }^{6,8,28}$

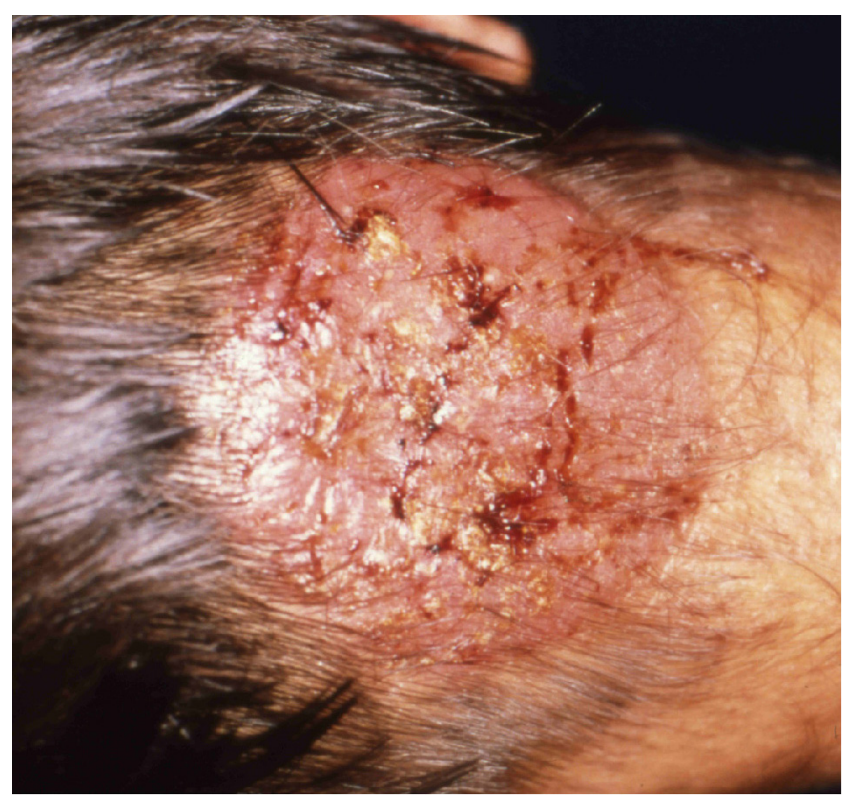

Figure 3. Kerion tinea capitis. (Photograph reprinted from Bennassar A, Grimalt R. Management of tinea capitis in childhood. Clin Cosmet Investig Dermatol. 2010;3:8998, with permission from Dove Medical Press Ltd.)

Diagnosis of tinea capitis often may be made by typical appearance. More definitive diagnosis is made by microscopy (branching hyphae and spores, the latter present within shortened hair stubs in the black dot type) and/or culture. ${ }^{6,828}$ Examination with Wood's lamp will reveal green fluorescence in the nowunusual occurrence of infection by M. canis. Recently, molecular techniques such as polymerase chain reaction (PCR) have been used for dermatophyte identification in some laboratories. ${ }^{27}$ The differential diagnosis depends somewhat on the type of tinea capitis. It may include seborrheic or atopic dermatitis (usually more diffuse than tinea capitis), psoriasis, discoid lupus erythematosus, lichen planus, nonfungal alopecia areata, traction alopecia and trichotillomania. ${ }^{8,27}$

Tinea Barbae: Tinea barbae is usually caused by Trichophyton species and is sometimes considered a variant of tinea capitis occurring in bearded areas of the face and neck (Figure 4). ${ }^{6}$ As with tinea capitis, there can be varying degrees of inflammation, pustules or exudates, scaling and crusting, alopecia or hair breakage near the skin surface. ${ }^{6}$

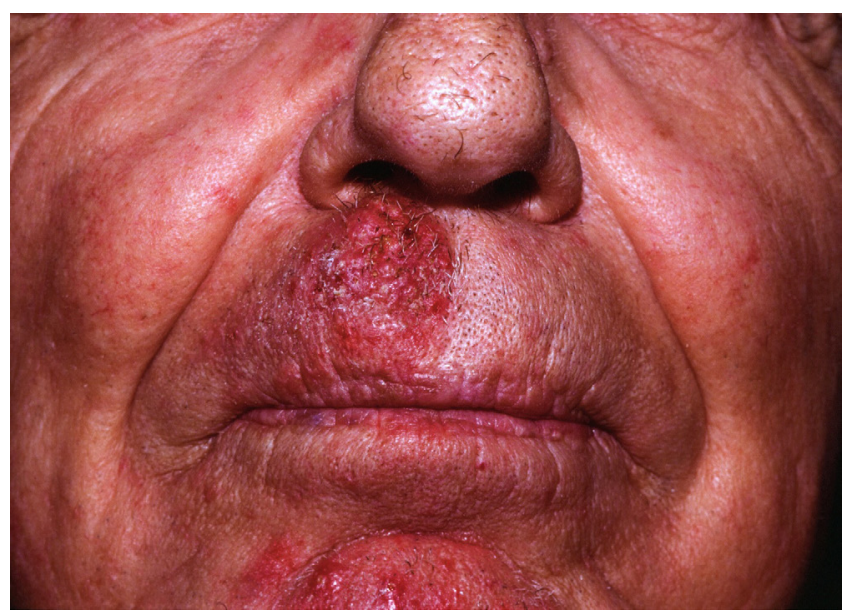

Figure 4. Tinea barbae. (Photograph courtesy of RegionalDerm.com and Dr. Gary White.)

Tinea barbae should be differentiated from folliculitis or furunculosis caused by Staphylococcus species and other bacteria; Candida folliculitis; acne rosacea; acne vulgaris; pseudofolliculitis due to shaving; perioral, contact, irritant or Herpes dermatitis; sporotrichosis; or neoplasia (rare). ${ }^{6,8}$ Attempts at hair removal may differentiate dermatophyte tinea barbae from bacterial infection, as it is painless in the former, painful in the latter. $^{8}$

Tinea Faciei: Tinea faciei is dermatophyte infection of the nonbearded areas of the face. ${ }^{8}$ Affected patients may experience burning and itching, which is aggravated by sunlight exposure. Generally, erythematous circular lesions are present but are sometimes indistinct (particularly in dark-skinned individuals). The lesions may have varying degrees of raised edges or scaling. ${ }^{8}$ Differential diagnosis includes dermatitis of various types, rosacea or discoid lupus erythematosus. Potassium hydroxide $(\mathrm{KOH})$ preparation microscopy of scrapings from the active border may be useful in diagnosis. ${ }^{8}$

Sometimes subtle tinea faciei is referred to as "tinea incognito;" 
used to describe tinea corporis/cruris/pedis that is inappropriately treated with oral or high-potency topical steroids. ${ }^{6}$ In true tinea incognito the face and arms are more commonly involved. ${ }^{29}$ The changed appearance results in diminished erythema without a typical scaling red border, irregular outlines, a folliculitis appearance and/or other combinations of papules, pustules or nodules. ${ }^{6,29,30}$ Thus, tinea incognito can mimic a variety of skin diseases, including those mentioned for tinea faciei plus psoriasis, impetigo, pustular dermatosis, erythema migrans, lichen planus and others. ${ }^{29,30}$ Diagnosis may be made by $\mathrm{KOH}$ preparation microscopy or histopathology. ${ }^{29,30}$

Tinea Corporis: Tinea corporis (ie, body ringworm) classically presents as well-demarcated, single or multiple, annular erythematous scaly lesions with a raised border and central clearing (Figure 5). 6,8,9 Varying degrees of itching may be present, and borders occasionally contain pustules or follicular papules. ${ }^{8}$ Nonringworm forms may occur as a series of vesicles or erythematous plaques. ${ }^{9}$ Borders may be indistinct and typical features more variable in the immunocompromised. ${ }^{6}$

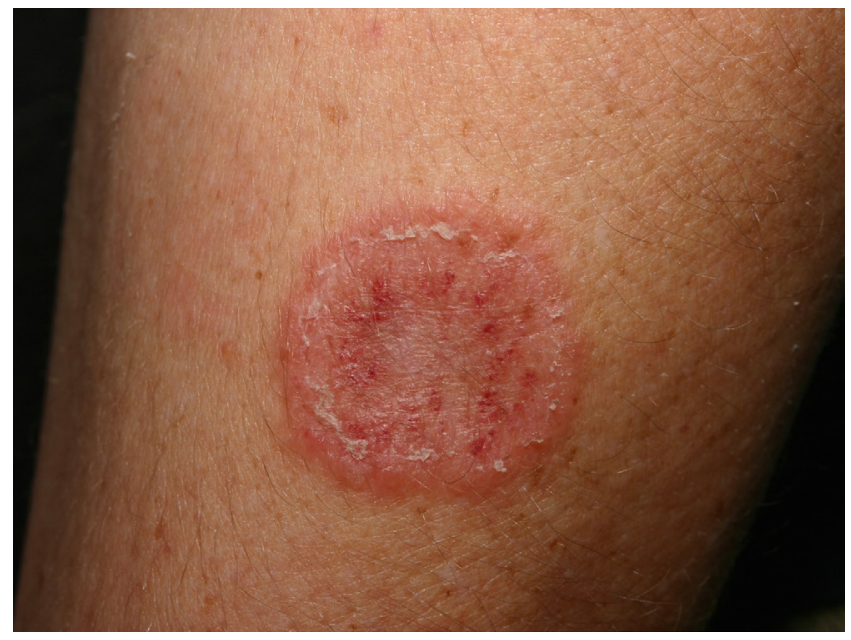

Figure 5. Tinea corporis. (Photograph courtesy of RegionalDerm.com and Dr. Gary White.)

Differential diagnosis includes nummular eczema, contact or other dermatitis, granuloma annulare, psoriasis, Lyme disease, secondary and tertiary syphilis, lichen planus, pityriasis rosea and pityriasis rubra pilaris. ${ }^{8,9}$ Diagnosis is based on clinical appearance, although because of the broad differential diagnosis, confirmation by $\mathrm{KOH}$ preparation microscopy or fungal culture is recommended. ${ }^{9}$

Tinea Manuum: Tinea manuum is dermatophytosis of one or both hands (Figure 6). ${ }^{8}$ It frequently occurs along with tinea pedis; ${ }^{8}$ as such, some consider them the same entity. ${ }^{6}$ It is most commonly caused by Trichophyton species. ${ }^{7}$ Palms are typically hyperkeratotic and very dry; fingernails may be involved. ${ }^{8}$ It is frequently confused with dyshidrotic eczema, less commonly with contact dermatitis or psoriasis. ${ }^{8}$

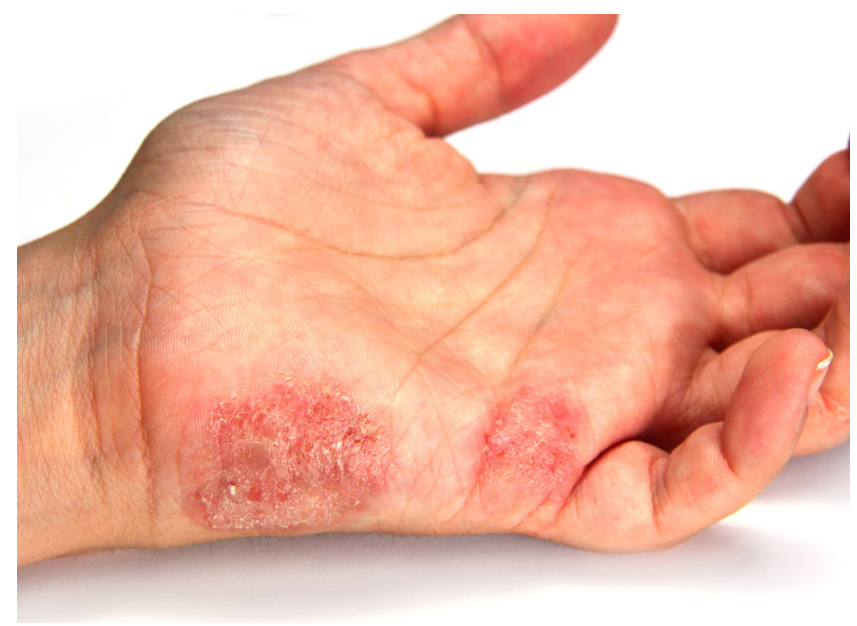

Figure 6. Tinea manuum.

Tinea Cruris: Tinea cruris, or "jock itch," is generally caused by Trichophyton species or E. floccosum. ${ }^{7}$ It is a dermatophyte infection of the groin (particularly the proximal medial thighs), perineal and perianal areas (Figure 7). ${ }^{6,8}$ More common in men, it may be acute or chronic, with varying degrees of itching and pain, and may extend to the buttocks or abdomen (but usually not the scrotum). ${ }^{6,8}$ Pustules and vesicles may be present at the (usually raised) active border. Varying amounts of maceration and excoriation may be present in addition to erythema and scaling. ${ }^{8}$ Tinea cruris often occurs with tinea pedis, and the latter may be the source of infection. ${ }^{8}$

Differential diagnosis includes candidal intertrigo (particularly in women), chafing or mechanical intertrigo, erythrasma, seborrheic or contact dermatitis, psoriasis, lichen simplex chronicus, Darier's disease, pemphigus vegetans and other entities., ${ }^{6,9}$ Tinea cruris can occur in infants in the diaper area, where 


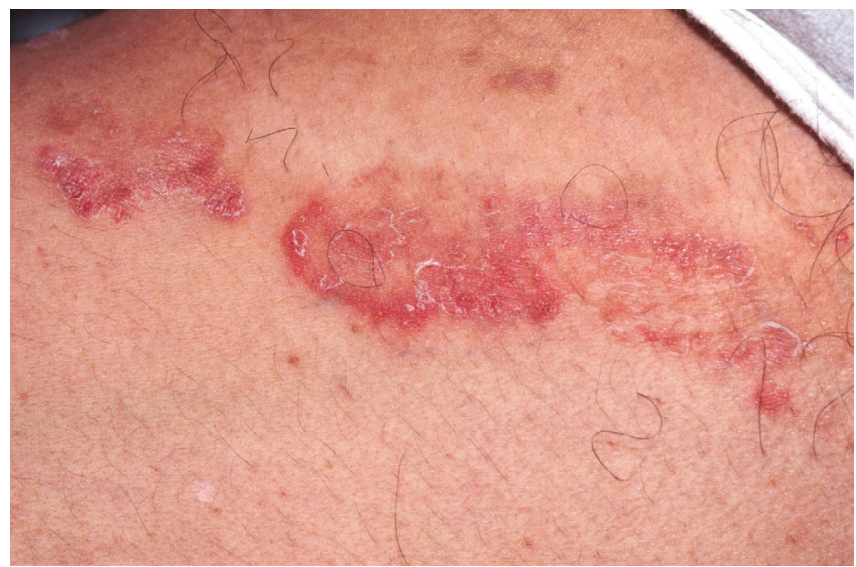

Figure 7. Tinea cruris. (Photograph courtesy of RegionalDerm.com and Dr. Gary White.)

it may be confused with Candida diaper dermatitis. ${ }^{6}$ Wood's lamp examination is useful primarily to rule out erythrasma caused by Corynebacterium, which produces a coral-colored fluorescence. ${ }^{9}$ Again, $\mathrm{KOH}$ preparation microscopy and/or fungal culture may be required for proper diagnosis.

Tinea Pedis: There are three common presentations of tinea pedis ("athlete's foot"), a dermatophyte infection generally caused by Trichophyton species and occasionally E. floccosum..$^{6-8}$ Most common is the interdigital type, which is characterized by itching, maceration, fissuring and peeling in between the toes (Figure 8) ${ }^{6,8}$ It especially involves the fourth and fifth toes. $^{8}$

The dry, hyperkeratotic type is usually caused by $T$. rubrum and occurs in a moccasin distribution on the sole, heel and sides of the foot. There are varying degrees of erythema, hyperkeratosis and scaling (and sometimes tiny vesicles). ${ }^{6,8}$

The vesicular type is a chronic (often lifetime) tinea pedis usually caused by Trichophyton interdigitale (Figure 9). ${ }^{6}$ Pruritic vesicles, pustules and sometimes bullae are typically found on the plantar arch and along the sides of the feet, including the heel adjacent to the thicker plantar stratum corneum. ${ }^{6}$ Wearing of occlusive shoes may exacerbate the condition. ${ }^{6}$ Not surprisingly, those with onychomycosis have occult or overt tinea pedis; and those with tinea manuum or cruris are apt. ${ }^{31}$

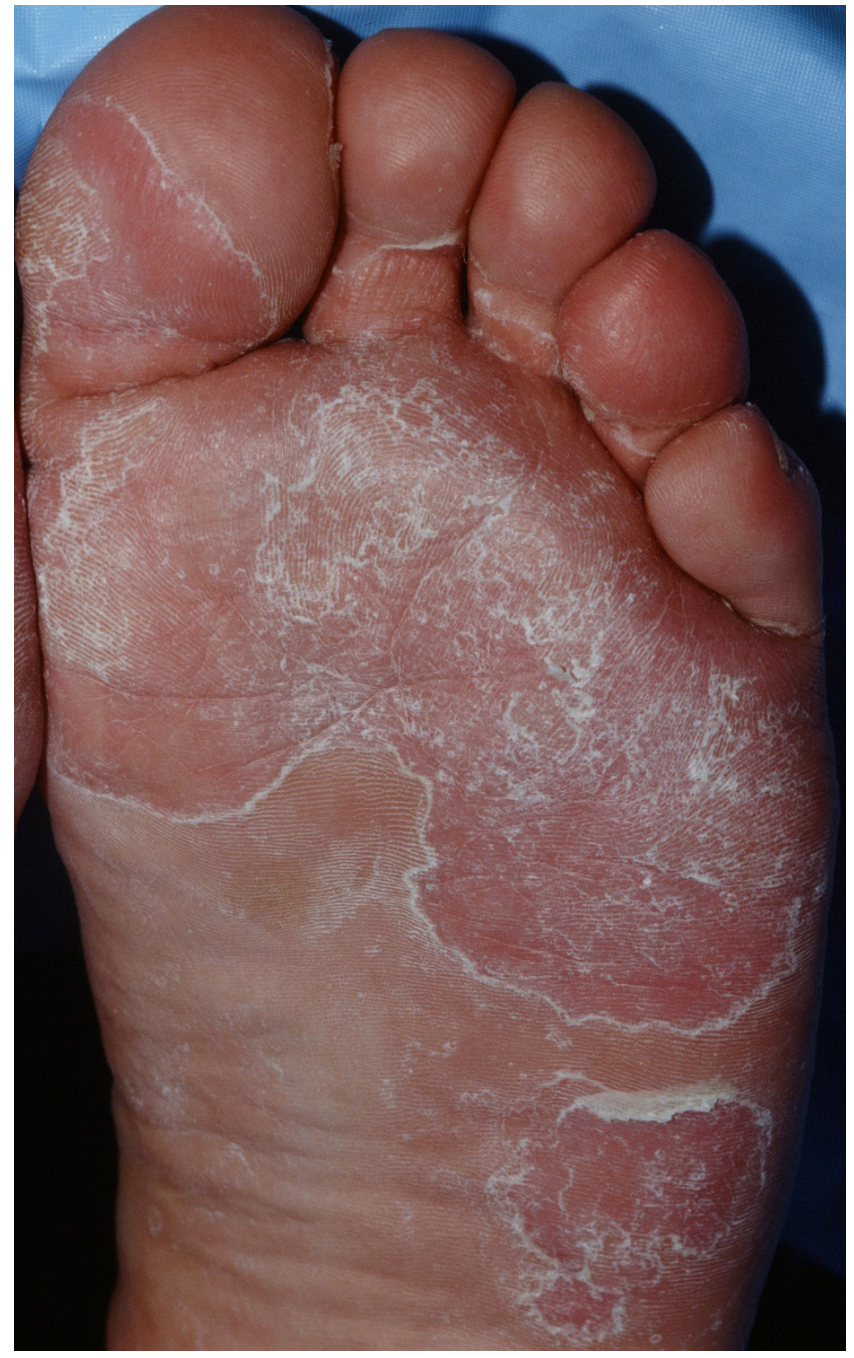

Figure 8. Tinea pedis. In this case, the interdigital type is present, in addition to spread along the sole of the foot which, when complete, would represent the moccasin-type distribution. (Photograph courtesy of RegionalDerm.com and Dr. Gary White.)

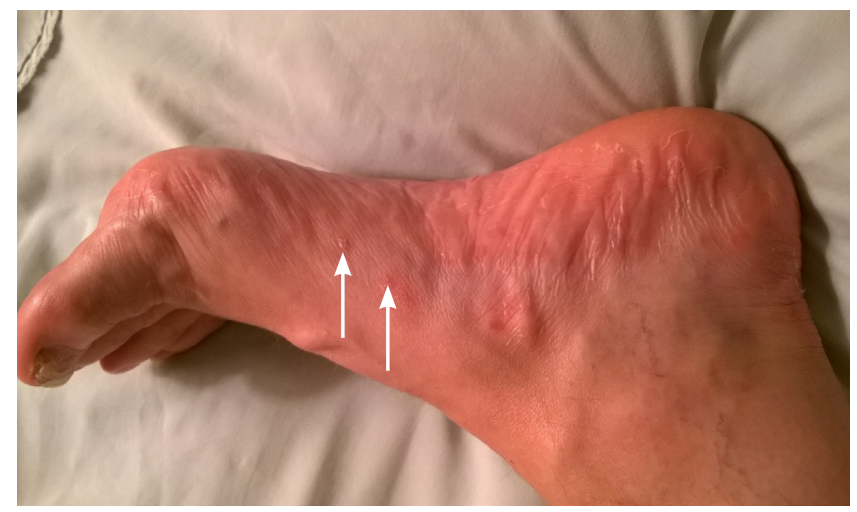

Figure 9. Mild case of mixed moccasin distribution tinea pedis and vescicular type (arrows) (original photograph). 
Differential diagnosis, depending on the type of tinea pedis, includes erythrasma, other bacterial infections, nondermatophyte mold causing similar signs and symptoms, Candida albicans or other yeast infection, contact dermatitis, eczema and pustular psoriasis. ${ }^{6,8,31}$ Secondary cellulitis, often from streptococci, may occur. $^{8}$ This is the result of fungal-induced skin breakdown between the toes, which allows pathogenic bacteria to colonize and invade. ${ }^{8}$ Secondary bacterial invasion is particularly likely in the acute ulcerative type (rare) of tinea pedis. ${ }^{31}$ This entity is an exacerbation of interdigital tinea pedis, with erosions and ulcers in the web spaces. ${ }^{31}$

Onychomycosis: Onychomycosis most commonly involves dermatophytes, and this large subset is termed tinea unguium. ${ }^{6,8} \mathrm{~A}$ multicenter survey of 15,000 Canadian patients visiting medical practices estimated a $6.5 \%$ prevalence of onychomycosis, a ratio of toenail to fingernail disease of 19:1 and proportions of dermatophyte etiology of $91 \%$ for toenails and $71 \%$ for fingernails. ${ }^{32}$ Most dermatophyte species were anthropophilic, and the significant odds ratio of reported prior trauma in patients with onychomycosis compared to those without was 5.4. ${ }^{32}$

Clinical presentations of onychomycosis are divided into five clinical types, which may vary according to etiologic agent and underlying diseases and genetic make-up. ${ }^{6,33}$ The most common $(90 \%)$ is distal and lateral subungual onychomycosis (Figure 10). It is most often due to T. rubrum, which progresses proximally to the cuticle, resulting in thickened, flaky nails with varying degrees of discoloration. ${ }^{6,33}$ Other types include leukonychia (a superficial white infection with patches or nail pits), proximal subungual onychomycosis (infection spreads distally from the cuticle), endonyx subungual (nail plate and bed both infected), and total dystrophic onychomycosis (entire nail involved in a combination of the previous types) ${ }^{6,33}$

Differential diagnosis includes traumatic onycholysis (which may lead to onychomycosis), psoriasis, lichen planus, contact or atopic dermatitis, nail dystrophy, subungual melanoma or squamous carcinoma and other disorders. ${ }^{6,8}$ Confirmatory diagnosis is made by fungal stain (or $\mathrm{KOH}$ preparation) and culture of scrapings of debris following alcohol swabbing and

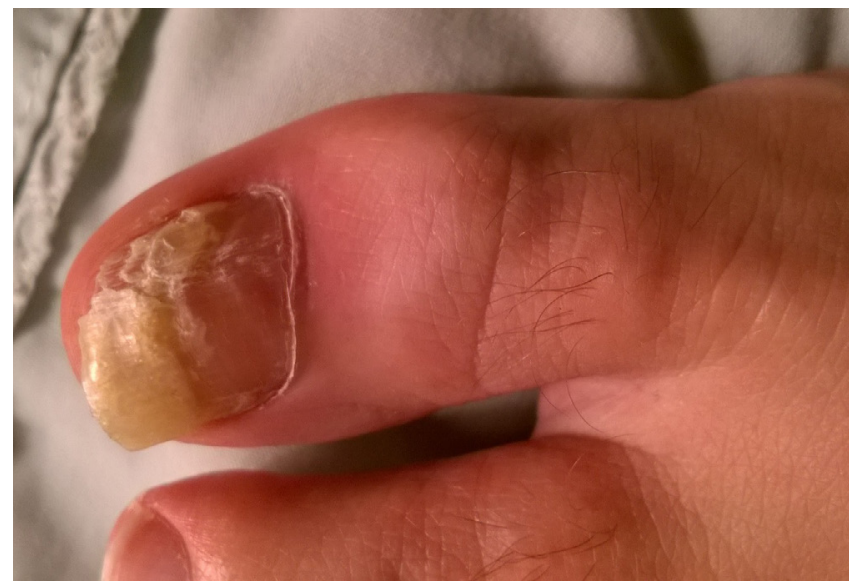

Figure 10. Distal and lateral subungual onychomycosis (original photograph). This photograph was taken several years after traumatic onycholysis.

nail clipping as described by Gupta et al. ${ }^{33}$ However, a recent analysis indicated that empiric treatment of onychomycosis with terbinafine is more cost-effective than confirmatory testing with fungal periodic acidSchiff stain or $\mathrm{KOH}$ prep. ${ }^{34}$ The opposite was true for treatment with $10 \%$ topical efinaconazole. ${ }^{34}$

Majocchi's Granuloma: Majocchi's granuloma occurs when dermatophytes like T. rubrum - or, rarely, nondermatophytes such as Aspergillus sp. invade the dermis and subcutaneous tissue, usually via disrupted hair follicles (Figure 11). ${ }^{6}$ This entity is usually precipitated by trauma or shaving, largely on

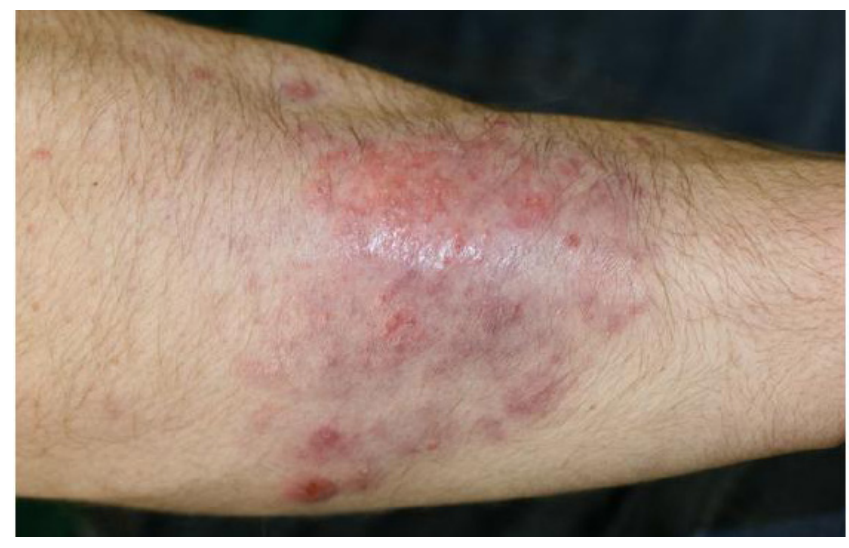

Figure 11. Majocchi's granuloma. (Photograph reprinted from Kurian A, Haber RM. Tinea corporis gladitorium presenting as Majocchi granuloma. ISRN Dermatol. 2011;2011:767589, with permission from the authors under the Creative Commons Attribution License.) 
the extremities, occasionally on the scalp or face. ${ }^{6,15,16}$ It is most common in children and usually presents as localized area of erythema, perifollicular papules, small nodules or pustules (with deeper plaques or larger nodules in the immunocompromised). ${ }^{15,16}$ Topical steroids or occlusion may promote this entity. ${ }^{6,15}$ As the differential diagnosis is quite broad, skin biopsy is usually necessary for confirmation. ${ }^{15}$

Id Reaction: The id reaction is an acute, local or more generalized, papulovesicular eruption that is usually remote from the site of dermatophyte infection (Figure 12). ${ }^{6,35}$ It occurs not from direct infection by dermatophytes or other fungal, bacterial, viral or parasitic infection, but rather from sensitization to circulating antigens, in this case, fungal. ${ }^{35}$ The reason that tinea pedis is the most commonly associated dermatophyte infection may be due to the fact that T. mentagrophytes is the most likely cause of acute dermatophyte foot infections and that this species induces a greater human response than others. ${ }^{35}$ The id reaction should not be mistaken for a drug reaction. ${ }^{6,35}$

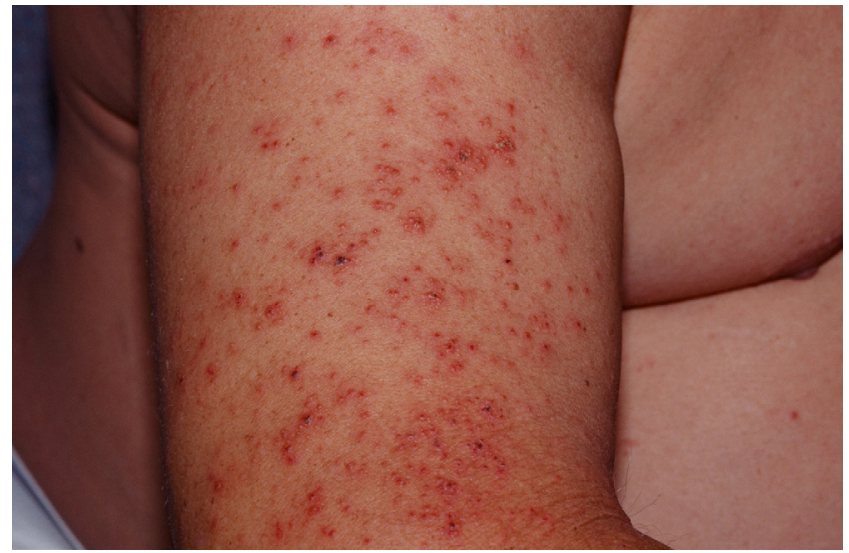

Figure 12. Id reaction, in this case on the arm, in response to a primary inflammatory condition the leg. (Photograph courtesy of RegionalDerm.com and Dr. Gary White.)

\section{Treatment}

Common treatment regimens are summarized in Table 2. . $8,15,16,27,35-41$ Localized superficial skin dermatophyte infections may be treated by topical antifungals. ${ }^{6,8,36}$ Adding topical corticosteroids to topical antifungal treatment is not suggested by guidelines and does not alter the rate of mycological cure, but may improve time to clinical cure due to treatment of inflammation. ${ }^{36}$
Tinea capitis, tinea barbae and Majocchi's granuloma require oral antifungal therapy. ${ }^{6,15,16,38}$ All treatments may require dosage and duration adjustments in immunocompromised individuals. . $^{6,16}$

A number of extracts from medicinal plants are being investigated as possible additional therapeutic agents for dermatophyte infections. ${ }^{42}$ Many have antidermatophytic activity in vitro, and some have exhibited synergy with conventional azole antifungals. ${ }^{42}$ Positive results were seen in mostly small trials using eucalyptus oil, tea tree (Melaleuca alternifolia) oil, Ageratina pichinchensis extract, a flavonoid extract and other agents. ${ }^{42-44}$ Regarding the former, eucalyptus containing Vicks ${ }^{\circledR}$ VapoRub $^{\mathrm{TM}}$ (Proctor \& Gamble Co., Cincinnati, OH) was applied to onychomycotic toenails for 48 weeks in an uncontrolled trial. ${ }^{45}$ Mycologic and clinical cure was seen in 5 of 15 subjects, and 10 had partial clearance with a variety of fungal etiologies. ${ }^{45}$

Three randomized controlled trials of tea tree oil alone for integumentary fungal infections have been reported. ${ }^{44}$ Satchell et al found a clinical cure after 4 weeks in $68 \%-72 \%$ with $25 \%-50 \%$ tea tree oil (placebo response: $39 \%$ ) and mycological cure in 55\%-64\% (placebo response: $31 \%$ ) of 120 evaluable patients with dermatophyte tinea pedis. ${ }^{46}$ Moderate to severe dermatitis that resolved with discontinuation was observed in $4 \% .{ }^{46}$ In a study of 70 subjects, Tong et al found $10 \%$ tea tree oil cream as clinically effective as topical tolnaftate at 4 weeks, but with mycological cure equivalent to placebo. ${ }^{47}$ Buck and colleagues compared 100\% tea tree oil to $1 \%$ clotrimazole solution in 117 subjects with onychomycosis. ${ }^{48}$ After 6 months, mycological cure was low and equivalent in both groups. Three months following the course, $56 \%$ in the tea tree oil group and $55 \%$ of the clotrimazole group had continued clinical improvement or resolution; local irritation, erythema or edema occurred in $8 \%$ of each group. ${ }^{48}$

\section{Nondermatophyte Infections Acquired Through Human Contact}

Malassezia species are commensal fungi of the skin and are discovered in most humans when they metabolize fatty acid secreted by skin cells. ${ }^{7}$ They are the etiologic agents of tinea versicolor, which is 
Table 2. Treatment of Dermatophyte Infections of the Integument

\begin{tabular}{|c|c|c|c|}
\hline Disease & Treatment & $\begin{array}{l}\text { Most common } \\
\text { side effects* }\end{array}$ & Comments \\
\hline $\begin{array}{l}\text { Localized } \\
\text { superficial; skin } \\
\text { dermatophyte; } \\
\text { tinea infections } \\
\text { (eg, corporis, } \\
\text { faciei, manuum, } \\
\text { cruris, pedis) }\end{array}$ & $\begin{array}{l}\text { Topical application of antifungal creams: } \\
\text { azoles (eg, clotrimazole, miconazole), } \\
\text { terbinafine, ciclopirox, tolnaftate, others. } \\
\text { Use for } 1-4 \text { weeks. } 6,8,36\end{array}$ & $\begin{array}{l}\text { Local reactions and } \\
\text { irritations, pruritis, } \\
\text { erythema, contact } \\
\text { dermatitis, skin } \\
\text { discoloration (may } \\
\text { vary with product) }\end{array}$ & $\begin{array}{l}\text { Area of most active fungal growth may } \\
\text { be on normal-appearing skin near well- } \\
\text { demarcated lesions; topical application } \\
\text { should include } 1 \text {-inch margin beyond } \\
\text { the border of the lesion. } \\
\text { For moccasin-type tinea pedis, } 40 \% \\
\text { urea cream may be useful adjunct. }^{6}\end{array}$ \\
\hline $\begin{array}{l}\text { Extensive or } \\
\text { recalcitrant } \\
\text { superficial skin } \\
\text { infections }\end{array}$ & $\begin{array}{l}\text { Itraconazole ( } 200 \mathrm{mg} \text { PO daily for } 1 \text { week or } \\
100 \mathrm{mg} \text { daily for } 2 \text { weeks; not FDA-indicated } \\
\text { for this use), terbinafine ( } 250 \mathrm{mg} \text { PO daily for } \\
2-4 \text { weeks; not FDA-indicated for this use), } \\
\text { or fluconazole ( } 150 \mathrm{mg} \text { PO weekly for } 2-4 \\
\text { weeks). }{ }^{6}\end{array}$ & $\begin{array}{l}\text { Edema, pruritis, rash, } \\
\text { Gl/upper respiratory } \\
\text { symptoms, sinusitis, } \\
\text { elevated liver enzymes, } \\
\text { headache, dizziness; } \\
\text { fever (terbinafine only) }\end{array}$ & $\begin{array}{l}\text { Pediatric treatment is similar, but } \\
\text { systemic medications are weight- } \\
\text { adjusted (consult current drug } \\
\text { monographs). }{ }^{37}\end{array}$ \\
\hline Tinea capitis & $\begin{array}{l}\text { Griseofulvin microsize (125-250 mg PO daily } \\
\text { for children } 13.6-22.7 \mathrm{~kg} \text { and } 250-500 \mathrm{mg} \text { daily } \\
\text { for those }>22.7 \mathrm{~kg} ; 500 \mathrm{mg} \text { daily for adults), or } \\
\text { griseofulvin ultramicrosize in ages } \geq 2 \text { years } \\
\text { ( } 125-187.5 \mathrm{mg} \text { PO daily for children } 16-27 \mathrm{~kg} \\
\text { and } 187.5-375 \mathrm{mg} \text { daily for those }>27 \mathrm{~kg} \text {; } \\
375 \mathrm{mg} \text { daily for adults). Therapy is typically } \\
6 \text { weeks but can be } 12 \text { weeks or longer. } \\
\\
\text { Terbinafine in ages } \geq 4 \text { years ( } 125 \mathrm{mg} \text { PO daily } \\
\text { if weight }<25 \mathrm{~kg}, 187.5 \mathrm{mg} \text { daily for } 25-35 \mathrm{~kg} \text {, } \\
\text { and } 250 \mathrm{mg} \text { daily for those }>35 \mathrm{~kg} \text { ). Treat for } \\
6 \text { weeks. }{ }^{38}\end{array}$ & $\begin{array}{l}\text { As noted above for } \\
\text { terbinafine }\end{array}$ & $\begin{array}{l}\text { Selenium sulfide ( } 1 \text { or } 2.5 \% \text { ) shampoo } \\
\text { or } 2 \% \text { ketoconazole shampoo may be } \\
\text { used for the first } 2 \text { weeks to reduce } \\
\text { transmission. }{ }^{37,38} \\
\text { Kerion should generally be treated with } \\
\text { griseofulvin. }{ }^{38} \text { Careful removal of crusts } \\
\text { with wet compresses may be helpful. }{ }^{27}\end{array}$ \\
\hline Tinea barbae & $\begin{array}{l}\text { Griseofulvin microsize (500 mg PO daily) or } \\
\text { ultramicrosize ( } 375 \text { mg daily) until infection clears. }\end{array}$ & $\begin{array}{l}\text { As noted above for } \\
\text { griseofulvin }\end{array}$ & \\
\hline $\begin{array}{l}\text { Majocchi's } \\
\text { granuloma }\end{array}$ & $\begin{array}{l}\text { Terbinafine ( } 250 \mathrm{mg} \text { PO daily for } 2-6 \text { weeks), } \\
\text { itraconazole ( } 200 \mathrm{mg} \text { PO twice daily for } 1 \text { week } \\
\text { for } 2 \text { or } 3 \text { pulses with } 2 \text { weeks between pulses, or } \\
100 \mathrm{mg} \text { PO daily for } 20-30 \text { days [all for adults]); } \\
\text { or griseofulvin ultramicrosize ( } 15 \mathrm{mg} / \mathrm{kg} \text { PO } \\
\text { daily for } 5-8 \text { weeks for children, or } 500 \mathrm{mg} \text { twice } \\
\text { daily for } 30 \text { days for older children and adults). }{ }^{15,16,37}\end{array}$ & $\begin{array}{l}\text { As noted above } \\
\text { for terbinafine and } \\
\text { griseofulvin }\end{array}$ & \\
\hline \multirow[t]{4}{*}{ Onychomycosis } & $\begin{array}{l}\text { Terbinafine (adult dosages of } 250 \text { mg PO daily } \\
\text { for } 6 \text { weeks for fingernail infections and } 12 \\
\text { weeks for toenail infections) appears to be the } \\
\text { preferred treatment for onychomycosis. }{ }^{6,35,39}\end{array}$ & $\begin{array}{l}\text { As noted above for } \\
\text { terbinafine }\end{array}$ & $\begin{array}{l}\text { Itraconazole ( } 200 \text { mg per day for } \\
12 \text { weeks) also may be used for } \\
\text { toenails, particularly for candidal and } \\
\text { nondermatophyte mold infections. }{ }^{39}\end{array}$ \\
\hline & $\begin{array}{l}\text { Topical alternatives: efinaconazole } 10 \% \text { solution } \\
\text { daily for } 48 \text { weeks (adults, toenails). }{ }^{40}\end{array}$ & $\begin{array}{l}\text { Ingrowing toenail } \\
(2.2 \%) \text {, dermatitis } \\
(2.1 \%) \text {, vesicles } \\
(1.5 \%){ }^{40}\end{array}$ & Complete cure rate of $18.5 \% .{ }^{40}$ \\
\hline & $\begin{array}{l}\text { Ciclopirox olamine } 8 \% \text { lacquer daily for } \\
48 \text { weeks, remove with alcohol every } 7 \text { days } \\
\text { (ages } \geq 12 \text { years). }\end{array}$ & $\begin{array}{l}\text { Pruritis, burning } \\
\text { sensation }\end{array}$ & $\begin{array}{l}\text { Complete cure rate of } 5.5 \%-8.5 \% \cdot^{36} \\
\text { May have best success with distal } \\
\text { subungual type and when upper nail } \\
\text { surface is filed or is otherwise more } \\
\text { easily penetrated. }{ }^{6,38,39}\end{array}$ \\
\hline & $\begin{array}{l}\text { Tavaborole } 5 \% \text { solution daily for } 48 \text { weeks } \\
\text { (adults, toenails). }{ }^{41}\end{array}$ & $\begin{array}{l}\text { Ingrowing toenail } \\
(2.2 \%) \text {, exfoliation } \\
(2.7 \%) \text {, erythema } \\
(1.6 \%) \text {, dermatitis } \\
(1.3 \%){ }^{41}\end{array}$ & $\begin{array}{l}\text { Surgical or chemical nail avulsion is an } \\
\text { additional or alternative option in some } \\
\text { cases. }^{39}\end{array}$ \\
\hline
\end{tabular}

*Source (unless otherwise noted): Micromedex 2.0 clinical decision support software (Truven Health Analytics Inc., Ann Arbor, MI). FDA, Food and Drug Administration; Gl, gastrointestinal; PO = by mouth. 
more likely to occur in immunocompromised patients - including those with human immunodeficiency virus - and in those with cortisol excess or malnutrition. ${ }^{7}$ These fungi may cause a folliculitis in the immunocompromised individual and trigger atopic and seborrheic dermatitis in susceptible individuals. ${ }^{7,49}$ While most Malassezia infections indeed arise from endogenous organisms, hospitalized neonates are colonized at high rates following birth, perhaps in part from the hands of health care workers. ${ }^{49}$

C. albicans is a common cause of cutaneous disease in infants. The yeast may be acquired from the mother during passage through the birth canal, or later in infancy from caregivers. ${ }^{7}$ Infant diaper rash, oral thrush, vaginitis, intertriginous candidiasis and hand dermatitis may all be caused by C. albicans and related yeasts. ${ }^{7}$ Candida species may be transmitted by casual or intermittent human contact, including sexual contact, through nosocomial transmission, and through fomites and surfaces such as those found in bathrooms..$^{50,51}$ However, most candidal infections beyond infancy arise from one's own endogenous strains. ${ }^{50}$

\section{Zoonotic Dermatophyte and Nondermatophyte Fungal Infections}

As noted earlier dermatophyte infections are the most common human fungal infections acquired from animals, and tinea capitis is the most predominant of these infections. ${ }^{12}$ In general, tinea capitis due to zoophilic, and the rare geophilic, dermatophyte species tend to cause a more inflammatory disease than anthropophilic species. ${ }^{10,12,27}$ The predominant zoophilic tinea capitis species in North America is $M$. canis. ${ }^{7,12}$ Kerion may be caused by zoophilic Trichophyton verrucosum or T. mentagrophytes. ${ }^{27}$

Occasionally, tinea barbae infections are zoonoses and may be related to farm work with stock animals or associated fomites. ${ }^{6,8}$ Domestic animals can transmit dermatologic fungal infections, especially tinea corporis and pedis, by direct contact. ${ }^{10,52-54}$ Zoophilic $T$. interdigitale may cause the rare, acute ulcerative type of tinea pedis described earlier. ${ }^{31}$

Malassezia pachydermatis fungemia has occurred as outbreaks in neonatal intensive care units, including one case in which the employee acquired the strain from a household dog. ${ }^{49}$
Sporotrichosis (discussed in detail in previous articles ${ }^{1,2}$ in this series) may be a zoonotic infection in some cases. ${ }^{10}$ There have been epidemiologic associations of this disease with armadillo hunting, fire-ant bites and contact with domestic cats infected with Sporothrix schenckii. ${ }^{10}$ The latter association has been controversial regarding whether it represented common environmental exposure or zoonotic transmission. ${ }^{55}$ There is molecular evidence favoring transmission of S. schenckii between cats and humans ${ }^{56}$ This may be an emerging route of transmission presently restricted to certain epidemic locales. ${ }^{57}$ Rarely, Cryptococcus (systemic and cutaneous) may be acquired by direct transmission from birds. ${ }^{53,58}$

\section{Prevention}

General measures for all persons to reduce the risk of transmission of the aforementioned fungal organisms include good general hygiene and handwashing, wearing loose-fitting cotton clothing, keeping feet clean and dry, laundering socks at $60^{\circ} \mathrm{C}$, keeping nails well-groomed, prompt showering after contact sports and not sharing personal care items. ${ }^{6,23,31,37}$ Persons with tinea capitis should discard or wash all brushes, combs and headwear. ${ }^{37}$

Prevention of recurrence of onychomycosis following clinical cure may be aided by periodic application of topical antifungal, specific to the nail and/or the plantar and interdigital foot; footwear decontamination; treatment of immediate family; and avoidance of public swimming pools. ${ }^{59}$ To prevent transmission of dermatophyte spores from household pets, carpet cleaning, thorough laundering of clothes and bedding and changing of heating/cooling system filters are recommended..$^{52}$

\section{Conclusions}

Human or animal contact may serve as the source of dermatophyte infections, candidal infections and, rarely, other types of superficial or deep fungal disease. These contagious fungal infections include some of the most commonly encountered diseases of the integument encountered in primary care practice. Differential diagnoses of these dermatophyte infections are broad, and proper recognition and appropriate topical or oral treatment of these entities is paramount. Specific and common sense hygiene measures may limit the spread of anthropophilic and zoonotic fungal infections. 


\section{Patient-Friendly Recap}

- Fungal infections transmitted through contact with other infected humans or animals, such as ringworm, are commonly encountered in primary care practice.

- The author reviewed the causes, symptoms and treatment of these contagious infections, with an emphasis on clinical presentation.

- Prevention measures include good hygiene and handwashing, keeping feet clean and dry, showering after contact sports, and not sharing personal care items.

- Persons with ringworm of the scalp should discard/wash brushes, combs and headwear.

\section{Conflicts of Interest}

None.

\section{References}

1. Baumgardner DJ. Soil-related bacterial and fungal infections. J Am Board Fam Med. 2012;25:734-44. CrossRef

2. Baumgardner DJ. Disease-causing fungi in homes and yards in the Midwestern United States. J Patient Cent Res Rev.2016;3:99-110. CrossRef

3. Baumgardner DJ. Freshwater fungal infections. J Patient Cent Res Rev. 2017;4:32-8. CrossRef

4. Bennett JE. Introduction to mycoses. In: Bennett JE, Dolin R, Blaser MJ (eds). Mandell, Douglas, and Bennett's Principles and Practice of Infectious Diseases, Eighth Edition. Philadelphia, PA: Elsevier Saunders, 2015, pp. 2874-8.

5. Hay RJ. Dermatophytosis (ringworm) and other superficial mycoses. In: Bennett JE, Dolin R, Blaser MJ (eds). Mandell, Douglas, and Bennett's Principles and Practice of Infectious Diseases, Eighth Edition. Philadelphia, PA: Elsevier, 2015, pp. 2985-994.

6. Reiss E, Shadomy HJ, Lyon GM III. Dermatophytosis. In: Fundamental Medical Mycology. Hoboken, NJ: WileyBlackwell, 2012, pp. 527-66.

7. Richardson MD, Moore CB, Summerbell RC, Gupta AK. Superficial and subcutaneous fungal pathogens. In: Cohen J, Powderly WG, Opal SM (eds). Infectious Diseases, 3rd Edition. Maryland Heights, MO: Mosby Elsevier, 2010, pp. 1853-67.

8. Hainer BL. Dermatophyte infections. Am Fam Physician. 2003;67:101-108.

9. Gupta AK, Chaudhry M, Elewski B. Tinea corporis, tinea cruris, tinea nigra, and piedra. Dermatol Clin. 2003;21:395400. $\underline{\text { CrossRef }}$

10. Wilson M, Lountzis N, Ferringer T. Zoonoses of dermatologic interest. Dermatol Ther. 2009;22:367-78. CrossRef

11. Hay RJ, Morris-Jones R. Outbreaks of sporotrichosis. Curr Opin Infect Dis. 2008;21:119-21. CrossRef

12. Aly R, Hay RJ, Del Pelacio A, Galimberti R. Epidemiology of tinea capitis. Med Mycol. 2000;38 Suppl 1:183-8. $\underline{\text { CrossRef }}$
13. Nenoff P, Krüger C, Ginter-Hanselmayer G, Tietz H-J. Mycology - an update. Part 1: Dermatomycoses: causative agents, epidemiology and pathogenesis. J Dtsch Dermatol Ges. 2014;12:188-209. CrossRef

14. Kamihama T, Kimura T, Hosokawa JI, Ueji M, Takase T, Tagami K. Tinea pedis outbreak in swimming pools in Japan. Public Health. 1997;111:249-53. CrossRef

15. Ilkit M, Durdu M, Karakaş M. Majocchi's granuloma: a symptom complex caused by fungal pathogens. Med Mycol. 2012;50:449-57. CrossRef

16. Feng WW, Chen HC, Chen HC. Majocchi's granuloma in a 3-year-old boy. Pediatr Infect Dis J. 2006;25:658-9.

17. Bronson DM, Desai DR, Barsky S, Foley SM. An epidemic of infection with Trichophyton tonsurans revealed in a 20-year survey of fungal infections in Chicago. $\mathrm{J} \mathrm{Am} \mathrm{Acad} \mathrm{Dermatol.}$ 1983;8:322-30. CrossRef

18. Borman AM, Campbell CK, Fraser M, Johnson EM. Analysis of the dermatophyte species isolated in the British Isles between 1980 and 2005 and review of worldwide dermatophyte trends over the last three decades. Med Mycol. 2007;45:131-41. CrossRef

19. Ilkit M, Demirhindi H. Asymptomatic dermatophyte scalp carriage: laboratory diagnosis, epidemiology and management. Mycopathologia. 2008;165:61-71. CrossRef

20. Zink A, Papanagiotou V, Todorova A, et al. Outbreak of Microsporum audouinii in Munich - the return of infectious fungi in Germany. Mycoses. 2014;57:765-70. CrossRef

21. Simpanya MF. Dermatophytes: their taxonomy, ecology and pathogenicity. In: Kushwaha RKS, Guarro J (eds). Biology of Dermatophytes and Other Keratinophilic Fungi. Bilbao, Spain: Revista Iberoamericana de Micología, 2000, pp. 1-12.

22. Dorman JM. Contagious diseases in competitive sport: what are the risks? J Am Coll Health. 2000;49:105-9. CrossRef

23. Likness LP. Common dermatologic infections in athletes and return-to-play guidelines. $J$ Am Osteopath Assoc. 2011;111:373-9. CrossRef

24. Brandi G, Sisti M, Paparini A, et al. Swimming pools and fungi: an environmental epidemiology survey in Italian indoor swimming facilities. Int J Environ Health Res. 2007;17:197206. CrossRef

25. Cohen BA, Schmidt C. Tinea gladiatorum. $N$ Engl J Med. 1992;327:820. $\underline{\text { CrossRef }}$

26. Kaufman G, Horwitz BA, Duek L, Ullman Y, Berdicevsky I. Infection stages of the dermatophyte pathogen Trichophyton: Microscopic characterization and proteolytic enzymes. Med Mycol. 2007;45:149-55. CrossRef

27. Hay RJ. Tinea capitis: current status. Mycopathologia. 2017;182:87-93. CrossRef

28. Panthagani AP, Tidman MJ. Diagnosis directs treatment in fungal infections of the skin. Practitioner. 2015;259:25-9.

29. Arenas R, Moreno-Coutiño G, Vera L, Welsh O. Tinea incognito. Clin Dermatol. 2010;28:137-9. CrossRef

30. Paloni G, Valerio E, Berti I, Cutrone M. Tinea incognito. J Pediatr. 2015;167:1450-e2. CrossRef

31. Canavan TN, Elewski BE. Identifying signs of tinea pedis: a key to understanding clinical variables. J Drugs Dermatol. 2015;14(10 Suppl):s42-7.

32. Gupta AK, Jain HC, Lynde CW, MacDonald P, Cooper EA, Summerbell RC. Prevalence and epidemiology of onychomycosis in patients visiting physicians' offices: a multicenter Canadian survey of 15,000 patients. J Am Acad Dermatol. 2000;43:244-8. CrossRef 
33. Gupta AK, Ryder JE, Summerbell RC. Onychomycosis: classification and diagnosis. J Drugs Dermatol. 2004;3:51-6.

34. Mikailov A, Cohen J, Joyce C, Mostaghimi A. Costeffectiveness of confirmatory testing before treatment of onychomycosis. JAMA Dermatol. 2016;152:276-81. CrossRef

35. Ilkit M, Durdu M, Karakaş M. Cutaneous id reactions: a comprehensive review of clinical manifestations, epidemiology, etiology, and management. Crit Rev Microbiol. 2012;38:191-202. CrossRef

36. El-Gohary M, van Zuuren EJ, Fedorowicz Z, et al. Topical antifungal treatments for tinea cruris and tinea corporis. Cochrane Database Syst Rev. 2014;(8):CD009992. CrossRef

37. Hawkins DM, Smidt AC. Superficial fungal infections in children. Pediatr Clin North Am. 2014;61:443-55. CrossRef

38. Ely JW, Rosenfeld S, Seabury Stone M. Diagnosis and management of tinea infections. Am Fam Physician. 2014;90:702-10.

39. Gupta AK, Paquet M, Simpson FC. Therapies for the treatment of onychomycosis. Clin Dermatol. 2013;31:544-54. CrossRef

40. Gupta AK, Elewski BE, Sugarman JL, et al. The efficacy and safety of efinaconazole $10 \%$ solution for treatment of mild to moderate onychomycosis: a pooled analysis of two phase 3 randomized trials. J Drugs Dermatol. 2014;13:815-20.

41. Elewski BE, Aly R, Baldwin SL, et al. Efficacy and safety of tavaborole topical solution, $5 \%$, a novel boron-based antifungal agent, for the treatment of toenail onychomycosis: results from 2 randomized phase-III studies. J Am Acad Dermatol. 2015;73:62-9. CrossRef

42. Lopes G, Pinto E, Salgueiro L. Natural products: an alternative to conventional therapy for dermatophytosis? Mycopathologia. 2017;182:143-67. CrossRef

43. Flores FC, Beck RC, da Silva CB. Essential oils for treatment of onychomycosis: a mini-review. Mycopathologia. 2016;181:9-15. CrossRef

44. Martin KW, Ernst E. Herbal medicines for treatment of fungal infections: a systematic review of controlled clinical trials. Mycoses. 2004;47:87-92. CrossRef

45. Derby R, Rodal P, Jackson C, Beutler A, Olsen C. Novel treatment of onychomycosis using over-the-counter mentholated ointment: a clinical case series. J Am Board Fam Med. 2011;24:69-74. CrossRef

46. Satchell AC, Saurajen A, Bell C, Barnetson RS. Treatment of interdigital tinea pedis with $25 \%$ and $50 \%$ tea tree oil solution: a randomized, placebo-controlled, blinded study. Australas $J$ Dermatol. 2002;43:175-8. CrossRef
47. Tong MM, Altman PM, Barnetson RS. Tea tree oil in the treatment of tinea pedis. Australas J Dermatol. 1992;33:145-9. CrossRef

48. Buck DS, Nidorf DM, Addino JG. Comparison of two topical preparations for the treatment of onychomycosis: Melaleuca alternifolia (tea tree) oil and clotrimazole. J Fam Pract. 1994;38:601-5.

49. Reiss E, Shadomy HJ, Lyon GM III. Dermatomycoses. In: Fundamental Medical Mycology. Hoboken, NJ: WileyBlackwell, 2012, pp. 567-88.

50. Reiss E, Shadomy HJ, Lyon GM III. Candidiasis and less common yeast genera. In: Fundamental Medical Mycology. Hoboken, NJ: Wiley-Blackwell, 2012, pp. 251-301.

51. Gerhardts A, Hammer TR, Balluff C, Mucha H, Hoefer D. A model of the transmission of micro-organisms in a public setting and its correlation to pathogen infection risks. $J$ Appl Microbiol. 2012;112:614-21. CrossRef

52. Goldstein EJ. Household pets and human infections. Infect Dis Clin North Am. 1991;5:117-30.

53. Akritidis N. Parasitic, fungal and prion zoonoses: an expanding universe of candidates for human disease. Clin Microbiol Infect. 2011;17:331-5. CrossRef

54. Riley PY, Chomel BB. Hedgehog zoonoses. Emerg Infect Dis. 2005;11(1):1-5. CrossRef

55. Hay RJ, Morris-Jones R. Outbreaks of sporotrichosis. Curr Opin Infect Dis. 2008;21:119-21. CrossRef

56. Reis RS, Almeida-Paes R, Muniz Mde M, et al. Molecular characterisation of Sporothrix schenckii isolates from humans and cats involved in the sporotrichosis epidemic in Rio de Janeiro, Brazil. Mem Inst Oswaldo Cruz. 2009;104:769-74. CrossRef

57. de Araujo ML, Rodrigues AM, Fernandes GF, de Camargo ZP, de Hoog GS. Human sporotrichosis beyond the epidemic front reveals classical transmission types in Espírito Santo, Brazil. Mycoses. 2015;58:485-90. CrossRef

58. Jorn KS, Thompson KM, Larson JM, Blair JE. Polly can make you sick: pet bird-associated diseases. Cleve Clin J Med. 2009;76:235-43. CrossRef

59. Gupta AK, Elewski BE, Rosen T, et al. Onychomycosis: strategies to minimize recurrence. $J$ Drugs Dermatol. 2016;15:279-82.

(C) 2017 Aurora Health Care, Inc. 